\title{
Blood and urine concentrations of aluminium among workers exposed to aluminium flake powders
}

\author{
Karl Göran Ljunggren, Vitauts Lidums, Bengt Sjögren
}

\begin{abstract}
In a group of workers exposed to aluminium flake powders, blood and urine concentrations of aluminium were assessed before and after vacation. Another group was investigated after retirement. Workers currently exposed to aluminium flake powders had urinary concentrations of the metal 80-90 times higher than those in occupationally non-exposed referents. The calculated half life for concentrations of aluminium in urine was five to six weeks based on four to five weeks of non-exposure. Among the retired workers the half lives varied from less than one up to eight years and were related to the number of years since retirement. These results indicate that aluminium is retained and stored in several compartments of the body and eliminated from these compartments at different rates.
\end{abstract}

Aluminium was suspected of causing encephalopathy among dialysis patients in $1976^{1}$ and this suspicion has been confirmed in later studies. ${ }^{23}$ The metal has also been suspected of being a causative agent in Alzheimer's disease although the mechanism remains obscure. ${ }^{4}$ One case of dementia and pulmonary fibrosis in an aluminium powder production worker was described in $1962 .{ }^{5}$ Workers manufacturing aluminium flake powders and aluminium welders had the highest blood and urine concentrations of aluminium in a survey of workers exposed to different forms of aluminium. ${ }^{6}$ Welders exposed to aluminium accumulate the metal in the body and their urinary concentrations increase with the number of exposed years. ${ }^{78}$

The purpose of this study was to assess aluminium concentrations in blood and urine among flake pow-

Industrial Health Centre (Hälsocentralen), John Bauersgatan 4, S-552 42 Jönköping, Sweden

K G Ljunggren

Department of Occupational Medicine, National Institute of Occupational Health, S-171 84 Solna, Sweden

B Sjögren, V Lidums der exposed workers before and after vacation and after retirement to estimate whether the concentrations decreased, and to what extent.

\section{Subjects}

Thirteen workers exposed to aluminium flake powder were investigated before and after four to five weeks of vacation. All were men with a mean age of $32 \cdot 6$ (range 22-61 years) and a mean exposure time of 5.2 years. Ten retired men were also included in the study. Eight had worked mainly with flake powder production and two (VJ and HL) mainly with "atomised" aluminium powder production. Their mean age was 67.9 (range $59-81$ years).

The referents were two men and three women and they were all working in the office of the same plant as the exposed workers. Their mean age was $52 \cdot 4$ (range 42-59 years). The only participant to have taken antacids was one of the referents (GF) who had sporadically used these since 1975 .

\section{EXPOSURE}

In this plant aluminium flake powders are manufactured. Solid aluminium is melted and "atomised" by means of compressed air to form more or less spherical particles, about $150 \mu \mathrm{m}$ in diameter. The powder is subsequently ball milled with white spirit. A second line of production is direct ball milling of mechanically shredded aluminium foil to give the same end product. After drying, the flake powders consist of flakes varying from five to $200 \mu \mathrm{m}$ in diameter and from 0.05 to $1 \mu \mathrm{m}$ in thickness. These flake powders are used for the production of explosives, light concrete, and pigments, and as a component in roof coating materials.

\section{Methods}

SAMPLING

Blood samples were collected in polystyrene test tubes with polypropylene lids. Urine was voided into $500 \mathrm{ml}$ polyethylene bottles with lids of the same material. All vessels used for sampling, storing, and analysis were carefully cleaned. They were soaked in a solution of $5 \%$ RBS- 25 and $1 \%$ EDTA for several hours, then rinsed with water, scaked in $50 \%$ nitric acid overnight, and rinsed thoroughly with ion free water purified by the Milli-Q system. Test tubes, autosampler cups, and small bottles were dried in a 
vacuum desiccator to avoid contamination by dust. For the same reason the urine bottles were not dried; only shaken out and capped immediately after rinsing.

Venous blood was taken through a stainless steel needle which was rinsed with some $\mathrm{ml}$ of the patients blood before sampling.

Urine was voided after personal instructions to avoid contamination. At the laboratory two portions of each urine sample were poured into small polyprophylene bottles. One was preserved for assessment of creatinine. A portion of $9.5 \mathrm{M}$ nitric acid, equivalent to $2 \%$ of the sample volume, was added to the other for later determination of aluminium (the nitric acid was purified by sub-boiling distillation).

Urine and blood samples were stored at $-20^{\circ} \mathrm{C}$ until analysis.

\section{ANALYSIS}

The concentration of aluminium was determined by electrothermal atomic absorption spectrometry using a Perkin-Elmer Zeeman/3030 system that comprised a microcomputer controlled spectrometer for graphite furnace analysis equipped with an ACZeeman magnet, a closed cooling system, an AS 60 autosampler, and a PR-100 printer. Analysis was performed on the wall of pyrolytically coated graphite tubes at the $396 \cdot 2 \mathrm{~nm}$ wavelength. The Zeeman effect for background correction enabled us to avoid errors from background absorption that can otherwise be large near the detection limit. ${ }^{9}$ Lower detection limits and enhanced accuracy have been obtained with the Zeeman/3030 instrument compared with the Perkin-Elmer 403 AAS with HGA-74 GF system and deuterium background correction that was used in our investigation in $1980 .{ }^{6}$

Blood was homogenised and diluted by adding $100 \mu \mathrm{l}$ of the sample to $200 \mu \mathrm{l}$ of $5 \mathrm{M}$ ammonia solution and $100 \mu \mathrm{l}$ water (or a standard solution) in the autosampler cup. The autosampler was programmed to inject $25 \mu \mathrm{l}$ of the mixture followed by a further $25 \mu \mathrm{l}$ of $5 \mathrm{M}$ ammonia matrix modifier to avoid a build up of a considerable residue in the graphite tube. Addition calibration was used for the calculation of the blood results. The coefficient of variation has routinely been $3.6 \%$ at a concentration of aluminium of $1.48 \mu \mathrm{mol} / 1(40 \mu \mathrm{g} / 1)$.

Urine samples were diluted directly in the autosampler cups with an equal volume of water. More water was added when the content of aluminium was higher. Twenty microlitres were routinely injected into the graphite furnace followed by $20 \mu \mathrm{l}$ of a matrix modifier, $5 \mathrm{M}$ ammonia purified by isothermal distillation. ${ }^{10}$ Calibration by addition of standards gave a $3.3 \%$ coefficient of variation at an aluminium concentration of $1.48 \mu \mathrm{mol} / 1(40 \mu \mathrm{g} / \mathrm{l})$.

Consequent blanks for both blood and urine were run each day and the sample results were corrected for the blank values obtained. The concentrations of aluminium in blood and urine were mostly calculated from the absorbance peak areas as these were more precise than peak heights. An exception was for the concentration near the lowest detection limit when peak heights were preferably used as they were influenced less from background noise. The detection limits for aluminium were $0.07 \mu \mathrm{mol}(2 \mu \mathrm{g} / \mathrm{l})$ for blood and $0.04 \mu \mathrm{mol} / 1(1 \mu \mathrm{g} / \mathrm{l})$ for urine.

Creatinine was determined by a photometric picric acid method on an Ultrolab reaction rate analyser LKB 8600.

\section{Calculations}

Assuming first order kinetics the decline of urine concentrations was calculated from mean values of $q$ in the equation $\left(A_{1}-A_{\infty}\right)=\left(A_{0}-A_{\infty}\right) \cdot e^{-q\left(t_{1}-t_{0}\right)}$, where $A_{0}$ is the urine concentration of aluminium at $t_{0}, A_{1}$ is the concentration at $t_{1}, A_{\infty}$ is the concentration at $t_{x}$, and $q$ is the elimination rate constant. $A_{\infty}$ was taken as the median concentration of aluminium in urine among the occupationally non-exposed referents. The corresponding biological half life can be calculated from $\ln 2 / \mathrm{q}$.

Among the retired workers $t_{0}$ was the year of retirement and $t_{1}$ was 1989 . The concentration of aluminium at $t_{0}$ was taken as the concentration that was measured in 1980 .

\section{Results}

The highest blood concentrations of aluminium were found among the workers currently exposed to aluminium flake powders (mean 0.46 and median $0.33 \mu \mathrm{mol} / 1$; table 1 ) compared with retired workers (median $0.11 \mu \mathrm{mol} / \mathrm{l}$; table 2 ), and occupationally non-exposed persons (median $<0.07-0.11 \mu \mathrm{mol} / 1$; table 3 ). Correspondingly the highest urine concentrations were found among the currently exposed workers (mean 7.54 and median $8.1 \mu \mathrm{mol} / \mathrm{l}$ ) and lower concentrations among retired workers (mean 0.74 and median $0.80 \mu \mathrm{mol} / \mathrm{l}$ ) and referents (median $0.09 \mu \mathrm{mol} / \mathrm{l}$ ). The currently exposed workers had no increase in blood or urine concentrations of aluminium related to exposure time.

The calculated half lives for urine concentrations during four to five weeks of exposure free vacation were 6.8 weeks based on $\mu \mathrm{mol} / 1$ and 5.2 weeks based on $\mathrm{mmol} / \mathrm{mol}$ creatinine. No obvious relation existed between half lives and exposure time. The blood concentrations were close to the reference values and were therefore not used for calculations of half lives. The non-exposure time among the retired workers varied from six months to 14 years. The half life was 0.7 years based on urine measurements for two workers with three years of retirement, 2.3 years for two with seven years of retirement and 7.9 years for two with nine years of non-exposure. 
Table 1 Blood and urine concentrations of aluminium before and after four to five weeks of vacation among workers exposed to aluminium flake powders

\begin{tabular}{|c|c|c|c|c|c|c|c|}
\hline \multirow[b]{3}{*}{ Worker } & \multirow{3}{*}{$\begin{array}{l}\text { No of } \\
\text { exposed years }\end{array}$} & & & \multicolumn{4}{|c|}{ Urinary aluminium concentrations } \\
\hline & & \multicolumn{2}{|c|}{ Blood aluminium conc $(\mu \mathrm{mol} / \mathrm{l})$} & \multicolumn{2}{|l|}{$\mu m o l / l$} & \multicolumn{2}{|c|}{ mmol/mol creatinine } \\
\hline & & Before & After & Before & After & Before & After \\
\hline $\begin{array}{l}\text { KJ } \\
\text { LT } \\
\text { RA } \\
\text { JB } \\
\text { BF } \\
\text { GG } \\
\text { LL } \\
\text { TB } \\
\text { KG } \\
\text { HB } \\
\text { CG } \\
\text { SJ } \\
\text { SN }\end{array}$ & $\begin{array}{r}1 \\
1 \\
1 \\
2 \\
2 \\
3 \\
3 \\
3 \\
5 \\
6 \\
8 \\
15 \\
17\end{array}$ & $\begin{array}{l}0.26 \\
0.82 \\
1.30 \\
0.52 \\
0.78 \\
0.15 \\
0.11 \\
0.37 \\
0.19 \\
0.52 \\
0.33 \\
0.33 \\
0.30\end{array}$ & $\begin{array}{l}0.22 \\
0.48 \\
0.89 \\
0.30 \\
0.93 \\
0.22 \\
0 \cdot 19 \\
0.07 \\
0.22 \\
0.44 \\
0.52 \\
0.30 \\
0.37\end{array}$ & $\begin{array}{r}12 \cdot 8 \\
3 \cdot 7 \\
11.9 \\
8 \cdot 1 \\
10.5 \\
8 \cdot 1 \\
2 \cdot 8 \\
1 \cdot 2 \\
5 \cdot 6 \\
9 \cdot 8 \\
11.9 \\
4.5 \\
7 \cdot 1\end{array}$ & $\begin{array}{r}3.9 \\
6.9 \\
12.0 \\
7.1 \\
10.5 \\
1.7 \\
1.6 \\
1.6 \\
9.9 \\
8.7 \\
1.3 \\
1.6 \\
4.3\end{array}$ & $\begin{array}{l}1.91 \\
0.47 \\
1.49 \\
0.62 \\
1.25 \\
0.54 \\
0.13 \\
0.07 \\
0.31 \\
0.95 \\
0.66 \\
0.50 \\
0.58\end{array}$ & $\begin{array}{l}0.52 \\
0.36 \\
1.46 \\
0.40 \\
0.53 \\
0.20 \\
0 \cdot 10 \\
0.08 \\
0.38 \\
0.74 \\
0.11 \\
0.27 \\
0.33\end{array}$ \\
\hline
\end{tabular}

Table 2 Blood and urine concentrations of aluminium among retired workers

\begin{tabular}{|c|c|c|c|c|c|c|c|c|}
\hline \multirow[b]{3}{*}{ Worker } & \multirow{3}{*}{$\begin{array}{l}\text { No of } \\
\text { exposed } \\
\text { years }\end{array}$} & \multirow{3}{*}{$\begin{array}{l}\text { Year of } \\
\text { retirement }\end{array}$} & \multirow{2}{*}{\multicolumn{2}{|c|}{ Blood aluminium conc $(\mu \mathrm{mol} / \mathrm{l})$}} & \multicolumn{4}{|c|}{ Urinary aluminium concentrations } \\
\hline & & & & & \multicolumn{2}{|l|}{$\mu \mathrm{mol} / \mathrm{l}$} & \multicolumn{2}{|c|}{$\begin{array}{l}\text { mmol/mol } \\
\text { creatinine }\end{array}$} \\
\hline & & & 1980 & 1989 & 1980 & 1989 & 1980 & 1989 \\
\hline $\mathrm{BN}$ & 9 & 1989 & $6 \cdot 33$ & 0.15 & $156 \cdot 67$ & $1 \cdot 19$ & $11 \cdot 60$ & 0.24 \\
\hline $\mathrm{BL}$ & 13 & 1986 & 0.41 & $<0.07$ & $10 \cdot 37$ & 0.93 & 1.08 & 0.06 \\
\hline $\mathrm{HL}$ & 13 & 1986 & 0.56 & 0.11 & 0.52 & 0.11 & 0.07 & 0.01 \\
\hline LB & 20 & 1982 & - & $<0.07$ & - & 0.52 & - & 0.07 \\
\hline NS & 20 & 1985 & - & 0.11 & - & 0.33 & - & 0.06 \\
\hline IL & 23 & 1984 & - & 0.11 & - & $1 \cdot 37$ & - & 0.12 \\
\hline AP & 26 & 1980 & 0.33 & 0.19 & 1.04 & $1 \cdot 19$ & 0.09 & 0.06 \\
\hline $\mathrm{JH}$ & 31 & 1982 & $1 \cdot 22$ & 0.19 & $8 \cdot 22$ & 0.89 & $1 \cdot 17$ & 0.07 \\
\hline GP & 43 & 1975 & 0.26 & $<0.07$ & $1 \cdot 15$ & 0.19 & 0.10 & 0.07 \\
\hline VJ & 50 & 1982 & 0.30 & $<0.07$ & 1.85 & 0.70 & 0.14 & 0.04 \\
\hline
\end{tabular}

Table 3 Blood and urine concentrations of aluminium among occupationally non-exposed persons before and after vacation

\begin{tabular}{|c|c|c|c|c|c|c|}
\hline \multirow[b]{3}{*}{ Person } & \multirow{2}{*}{\multicolumn{2}{|c|}{ Blood aluminium conc ( $\mu$ mol/l) }} & \multicolumn{4}{|c|}{ Urinary aluminium concentrations } \\
\hline & & & \multicolumn{2}{|l|}{$\mu \mathrm{mol} / \mathrm{l}$} & \multicolumn{2}{|c|}{ mmol/mol creatinine } \\
\hline & Before & After & Before & After & Before & After \\
\hline $\begin{array}{l}\text { AW } \\
\text { GB } \\
\AA \text { AB } \\
\text { GF } \\
\text { AS }\end{array}$ & $\begin{array}{r}<0.07 \\
0.11 \\
0.15 \\
<0.07 \\
0.19\end{array}$ & $\begin{array}{r}<0.07 \\
<0.07 \\
<0.07 \\
0.15 \\
0.11\end{array}$ & $\begin{array}{r}0.11 \\
0.15 \\
0.07 \\
<0.04 \\
<0.04\end{array}$ & $\begin{array}{r}0.15 \\
0.15 \\
<0.04 \\
0.11 \\
0.07\end{array}$ & $\begin{array}{r}0.01 \\
0.01 \\
0.02 \\
<0.02 \\
<0.01\end{array}$ & $\begin{array}{r}0.01 \\
0.05 \\
<0.01 \\
0.04 \\
0.01\end{array}$ \\
\hline
\end{tabular}

\section{Discussion}

Workers currently occupationally exposed to aluminium during flake powder production had 8090 times higher urinary aluminium concentrations than non-exposed persons. Long term exposed workers, however, did not excrete higher concentrations of aluminium compared with short term exposed workers and this is contrary to the situation in aluminium exposed welders. Such welders exposed for 20 years excreted 100 times the concentration found among referents. ${ }^{7}$

Among aluminium exposed welders the half life for urine concentrations was eight to nine days in welders exposed for less than one year and six months or longer for those exposed for more than 10 years. ${ }^{8}$ In this study of workers exposed to aluminium flake 
powder the calculated half life for aluminium in urine seemed to be nearly' constant despite varied exposure times. The differences between flake powder exposed and welding fume exposed workers might be explained by the character of the inhaled aluminium. Welding fume particles are generally smaller than 1 $\mu \mathrm{m}$ while aluminium flake powder particles are larger, as mentioned previously. It seems likely that the larger flake powder particles leave the lung parenchyma at a slower rate than the smaller welding fume particles.

The exposure in this plant does not seem to have improved significantly, when comparing flake powder exposed workers in $1980^{6}$ and 1989 , as the median blood concentration of aluminium was $0.48 \mu \mathrm{mol} / 1$ in 1980 (range $0.33-6.33 \mu \mathrm{mol} / \mathrm{l}, \mathrm{n}=11$ ) and the median urine concentrations were $3.22 \mu \mathrm{mol} / 1$ (range $0.33-156.7 \mu \mathrm{mol} / \mathrm{l}, \mathrm{n}=10$ ) and $0.25 \mathrm{mmol} / \mathrm{mol}$ creatinine (range $0.07-11.61 \mathrm{mmol} / \mathrm{mol}$ creatinine).

The increasing half life with longer exposure free intervals clearly indicates an accumulation of aluminium in several compartments. These compartments might be bone, spleen, liver, muscle tissue, and lungs, as they have all been shown to contain comparatively high concentrations of aluminium. ${ }^{112}$ Half lives for different organs have been estimated after a six hour infusion of aluminium lactate into rabbits. The calculated half lives were 113 days for spleen, 74 days for liver, 44 days for lung, and 42 days for serum according to Yokel and McNamara. ${ }^{13}$

Whole blood was analysed instead of plasma or serum to avoid contamination outside the clean air bench in our laboratory. The concentration of aluminium in whole blood has previously been investigated and was found to be around $8 \%$ higher than in plasma. ${ }^{6}$ In normal healthy occupationally non-exposed people the concentration of aluminium in blood is probably less than $0.4 \mu \mathrm{mol} / 1 .{ }^{14}$ Blood concentrations among the referents in this study were all below that despite the fact that one of the referents had taken aluminium containing antacids sporadically during the past 15 years. The small intraindividual variation seen before and after vacation might be explained by differences in intake of aluminium itself, or citrate, which may bind to aluminium and increase the gastrointestinal absorption, ${ }^{15}$ or other unknown factors.

Dialysis patients with mean concentrations of aluminium in serum of $2.2 \mu \mathrm{mol} / 1$ had a delayed response time and abnormalities in psychomoter function compared with healthy volunteers. ${ }^{2}$ Occupationally exposed groups have not yet been investigated with psychometric tests. Welders exposed long term to aluminium, however, had more neuropsychiatric symptoms compared with iron exposed welders ${ }^{16}$ and these aluminium welders, where investigated, had urine concentrations of aluminium about 100 times the referent value.

Our study clearly indicates that workers exposed to aluminium flake powders store the metal and excrete it slowly over many years. Whether this degree of exposure to aluminium poses a risk to the nervous system or other tissues has not yet been investigated.

This study has been. financed by the Swedish Work Environment Fund and Carlfors Bruk.

Requests for reprints to: Bengt Sjögren, Department of Occupational Medicine, National Institute of Occupational Health, S-171 84 Solna, Sweden.

1 Alfrey AC, LeGendre GR, Kaehny WD. The dialysis encephalopathy syndrome, possible aluminium intoxication. New England Journal of Medicine 1976;294:184-8.

2 Altmann P, Dhanesha U, Hamon C, Cunningham J, Blair J, Marsh F. Disturbance of cerebral function by aluminium in haemodialysis patients without overt aluminium toxicity. Lancet 1989;ii:7-12.

3 Schreeder MT, Favero MS, Hughes JR, Petersen NJ, Bennett $\mathrm{PH}$, Maynard JE. Dialysis encephalopathy and aluminum exposure: An epidemiologic analysis. $J$ Chronic Dis 1983;36:581-93.

4 Crapper McLachlan DR, Lukiw WJ, Kruck TPA. New evidence for an active role of aluminum in Alzheimer's disease. Can J Neurol Sci 1989;16:490-7.

5 McLaughlin AIG, Kazantzis G, King E, Teare D, Porter RJ, Owen R. Pulmonary fibrosis and encephalopathy associated with the inhalation of aluminium dust. $\mathrm{Br} J$ Ind Med 1962;19:253-63.

6 Siogren $B$, Lundberg I, Lidums V. Aluminium in the blood and urine of industrially exposed workers. $\mathrm{Br} J$ Ind $\mathrm{Med}$ 1983;40:301-4.

7 Sjögren B, Lidums V, Håkansson M, Hedström L. Exposure and urinary excretion of aluminum during welding. Scand $J$ Work Environ Health 1985;11:39-43.

8 Sjögren B, Elinder CG, Lidums V, Chang G. Uptake and urinary excretion of aluminum among welders. Int Arch Occup Environ Health 1988;60:77-9.

9 Frech W, Cedergren A, Cederberg C, Vessman J. Evaluation of some critical factors affecting determination of aluminium in blood, plasma or serum by electrothermal atomic absorption spectroscopy. Clin Chem 1982;28:2259-63.

10 Veillon C, Reamer DC. Preparation of high-purity volatile acids and bases by isothermal distillation. Anal Chem 1981;53: 549-50.

11 Alfrey AC. Aluminum metabolism in uremia. Neurotoxicology $1980 ; 1: 43-53$

12 Skalsky HL, Carchman RA. Aluminum homeostasis in man. Journal of the American College of Toxicology. 1983;2:405-23.

13 Yokel RA, McNamara PJ. Elevated aluminum persists in serum and tissues of rabbits after a six-hour infusion. Toxicol Appl Pharmacol 1989;99:133-8.

14 Elinder CG, Sjögren B. Aluminum. In: Friberg L, Nordberg $\mathrm{GF}$, Vouk VB, eds. Handbook on the toxicology of metals. Vol II, 2nd ed. Amsterdam: Elsevier Science Publishers, 1986: $1-25$.

15 Slanina P, Frech W, Ekström L-G, Lööf L, Slorach S, Cedergren A. Dietary citric acid enhances absorption of aluminium in antacids. Clin Chem 1986;32:539-41.

16 Sjögren B, Gustavsson P, Hogstedt C. Neuropsychiatric symptoms among welders exposed to neurotoxic metals. $\mathrm{Br} J$ Ind Med 1990;47:704-7.

Accepted 3 September 1990 